\title{
PENERAPAN SISTEM INFORMASI MANAJEMEN NIKAH (SIMKAH) DI KUA KECAMATAN JATINANGOR KABUPATEN SUMEDANG
}

\author{
Rizel Juneldi, Ramdani Wahyu Sururie \\ Hukum Keluarga, Fakultas Syariah dan Hukum, UIN Sunan Gunung Djati Bandung \\ Email: rizeljuneldi18@gmail.com, ramdaniwahyusururie@uinsgd.ac.id
}

\begin{abstract}
Abstrack
This research is motivated by the presence of an application in marriage data collection called the Marriage Management Information System or Simkah which has begun to be applied in various Religious Affairs Offices (KUA) in West Java, especially in KUA, Jatinangor District, Sumedang. Simkah is a policy program issued by the government to be applied to KUA in district which aims to facilitate the presentation of marriage data at the KUA. The purpose of this study was to describe the application of the Marriage Management Information System or Simkah in administrative services at KUA Jatinangor, Sumedang and its effectiveness. The method used in this research is descriptive method with a qualitative approach, namely research that seeks to reveal and interpret developing phenomena. In this case, the researcher went directly to the field, involving KUA Jatinangor, Sumedang Regency. The data found shows that Simkah at KUA Jatinangor, Sumedang Regency has been implemented but is still constrained, especially in terms of the readiness of the KUA's human resources. In some cases, it was found that it was difficult to use this application, including the complexity of inputting marriage data. Thus it can be concluded that the application of Simkah has helped facilitate data collection on marriages throughout Indonesia but it is still not effective in data entry at the local KUA.
\end{abstract}

Keywords: Effectiveness, Marriage Management System, Religious Affairs Offices.

\begin{abstract}
Abstrak
Penelitian ini dilatarbelakangi oleh hadirnya aplikasi dalam pendataan pernikahan yang disebut dengan Sistem Informasi Manajemen Nikah atau Simkah yang sudah mulai diterapkan diberbagai Kantor Urusan Agama (KUA) di Jawa Barat, khususnya di KUA Kecamatan Jatinangor Kabupaten Sumedang. Simkah merupakan sebuah program kebijakan yang dikeluarkan oleh pemerintah agar diterapkan pada KUA Kecamatan yang bertujuan untuk memudahkan dalam penyajian data pernikahan di KUA. Tujuan penelitian ini untuk mendeskripsikan penerapan Sistem Informasi Manajemen Nikah atau Simkah dalam pelayanan administrasi di KUA Jatinangor Kabupaten Sumedang dan efektivitasnya. Metode yang digunakan dalam penelitian ini yaitu metode deskriptif dengan pendekatan kualitatif, yaitu penelitian yang berusaha mengungkapkan dan menginterpretasikan fenomena yang tengah berkembang. Dalam hal ini peneliti terjun langsung ke lapangan yaitu melibatkan KUA Jatinangor Kabupaten Sumedang. Data yang ditemukan menunjukkan bahwa Simkah di KUA Jatinangor Kabupaten Sumedang sudah diimplementasikan namun masih terkendala terutama dalam hal kesiapan SDM KUA. Pada beberapa kasus ditemukan
\end{abstract}


kesulitan menggunakan aplikasi ini, diantaranya kerumitan dalam menginput data nikah. Dengan demikian dapat disimpulkan bahwa penerapan Simkah telah membantu mempermudah pendataan nikah seluruh Indonesia namun masih belum efektiv dalam penginputan datanya di KUA setempat.

Kata Kunci: Efektivitas, Sistem Manajemen Nikah, Kantor Urusan Agama

\section{PENDAHULUAN}

Kementerian Agama Republik Indonesia terus berupaya meningkatkan layanan pernikahan bagi pasangan calon pengantin yang akan menikah melalui aplikasi Simkah, yaitu Sistem Informasi Manajemen Nikah. Aplikasi ini berbasis windowas yang digunakan untuk mengumpulkan data nikah dari seluruh Kantor Urusan Agama di wilayah Republik Indonesia secara "on-line". Tujuan dari hadirnya aplikasi berbasis teknologi ini untuk membantu mengecek nomor seri yang kemungkinan ganda, mengurangi kesalahan dalam hal pemalsuan serta mampu mengecek identitas mempelai dari berbagai kemungkinan.

Simkah ini dipandang perlu dalam upaya meningkatkan kualitas dan kinerja pelayanan administrasi nikah pada Kantor Urusan Agama (KUA) Kecamatan, Program Simkah merupakan salah satu program aplikasi yang dapat digunakan secara khusus, yang dibuat untuk kepentingan pencatatan pernikahan di KUA Kecamatan yang ada di seluruh Indonesia. Program ini menggunakan fasilitas internet yang dipandang cara yang lebih tepat, cepat dan aman

Sistem informasi pencatatan nikah pada awalnya hanya ditemukan dalam Peraturan Menteri Agama Nomor 11 Tahun 2007 pasal 5 ayat (2) yang menyebutkan bahwa "Pemberitahuan kehendak nikah dilakukan secara tertulis dengan mengisi formulir pemberitahuan dan dilengkapi persyaratan". Namun pada perkembangannya, berbagai macam inovasi dalam pelayanan nikah telah dilakukan, hingga pada tahun 2013 diterbitkan sebuah aturan dari Intruksi Direktur Jendral Bimbingan Masyarakat Islam Nomor II/369 Tahun 2013 Tentang Penerapan Sistem Informasi Manajemen Nikah (Simkah) pada Kantor Urusan Agama. ${ }^{1}$ Salah satu fungsi dalam penyelenggaraan pemerintah adalah penyelenggaraan pelayanan publik yang telah menjadi kewajiban dari aparatur pemerintahan itu sendiri. Simkah atau Sistem Informasi Manajeman Nikah merupakan sebuah program aplikasi komputer yang berbasis windows yang berguna untuk mengumpulkan data-data nikah dari seluruh Kantor Urusan Agama (KUA) di Wilayah Republik Indonesia secara online. Data yang dikumpulkan tersebut akan secara otomatis tersimpan dengan aman di Kantor Urusan

\footnotetext{
${ }^{1}$ Kantor Wilayah Kementrian Agama Provinsi Bengkulu, Buku Panduan Aplikasi Sistem Informasi Manajemen Nikah (SIMKAH), hlm. 2
}

180 Al-Ahwal Al-Syakhsiyyah : Jurnal Hukum dan Peradilan Islam 
Agama setempat, mencakup kabupaten/kota di Kantor Wilayah Provinsi dan di Bimas Islam. $^{2}$

Data-data yang dikumpulkan melalui Simkah akan berguna untuk membuat berbagai analisa dan laporan yang sesuai dengan keperluan. Dalam perkembangannya, program Simkah banyak mendapat respon dari berbagai pihak. Beberapa diantaranya memberikan tanggapan yang positif seperti dari operator Simkah pada Kantor Urusan Agama (internal) maupun dari masyarakat secara umum (eksternal). Respon yang membangun ini tentunya sangat diperlukan oleh para pengelola Simkah karena pada akhirnya dapat menjadi bahan evaluasi untuk Pengembangan Sistem Informasi Nikah itu sendiri. Program Simkah ini dipandang perlu dalam upaya meningkatkan kualitas serta kinerja pelayanan administrasi nikah pada Kantor Urusan Agama (KUA) Kecamatan, maka sejak tahun 2007 Dirjen Bimbingan Masyarakat Islam (Bimas Islam) telah berkomitmen meningkatkan kapasitas KUA melalui perbaikan pelayanan berbasis IT (Informasi dan Teknologi). Hal tersebut berlaku bagi pelayanan nikah mengenai pencatatan pernikahan yang dilakukan secara manual. ${ }^{3}$

Penyeragaman data tentu sangat diperlukan karena diharapkan dapat lebih efektif dan efisien sehingga penanganannya menjadi lebih mudah. Program Simkah ini adalah jawaban dari segala permasalahan mengenai pencatatan data yang dapat digunakan dan khusus dibuat untuk kepentingan tersebut. Penggunaan jaringan internet pada program Simkah dipandang sebagai cara yang lebih tepat, cepat dan aman. ${ }^{4}$ Karena penyajian data yang baik serta akurat akan menentukan arah pembangunan agama di masa mendatang. Penyajian data tersebut diibaratkan sebagai sebuah barang yang perlu dikemas dan disajikan dengan rapi dan baik sehingga dapat lebih menarik perhatian orang yang akan menikmatinya.

Sistem informasi manajemen nikah ini hanya diterapkan pada sebagian Kantor Urusan Agama yang letaknya di kota-kota besar. Salah satu Kantor Urusan Agama yang telah menerapkan sistem informasi manajemen nikah secara online adalah Kantor Urusan Agama (KUA) Jatinangor. KUA Jatinangor memanfaatkan informasi secara online dalam melakukan manajemen nikah, seperti merekap data-data pernikahan yang telah dilaksanakan, menerima pengajuan permohonan dan pendaftaran calon pasangan nikah. Selain itu, dimanfaatkan dalam mendata kasus-kasus talak, rujuk dan wakaf. Semua penelitian mengenai pelayanan publik berupa program Simkah yang sudah di terapkan di KUA Jatinangor yang memiliki topik menarik untuk peneliti tuangkan dalam tulisan ini. Tulisan ini memfokuskan pada menjawab dua pertanyaan

${ }^{2}$ Rizadian Mayangsari dan Eva Hany Fanida, "Penerapan Sistem Informasi Manajemen Nikah (Simkah)". Jurnal Hukum. Vol. 3, No. 1, Januari, 2012.

${ }^{3}$ Kementerian Agama RI, Buku Panduan Aplikasi Sistem Informasi Manajemen Bimas Islam (SIMBI), (Jakarta: Dirjen Bimas Islam, 2013), hlm 1

${ }^{4}$ Majalah Ditjen Bimas Islam Kemenag RI, Paradigma Baru KUA,(Jakarta: Edisi No. 1/Tahun 1/2014), hlm. 4 
Pertama, Bagaimana penerapan Simkah dalam pelayanan administrasi di Kantor Urusan Agama Jatinangor Kabupaten Sumedang, dan Kedua, Bagaimana efektivitas Simkah di Kantor Urusan Agama Jatinangor Kabupaten Sumedang.

\section{METODE PENELITIAN}

Metode pengumpulan data yang dilakukan oleh peneliti adalah melalui wawancara. Dalam hal ini peneliti terjun langsung ke lapangan yaitu melibatkan Kantor Urusan Agama (KUA) Jatinangor Kabupaten Sumedang dengan mencari, menganalisis dan mempelajari data yang berkaitan dengan objek penelitian. Subyek penelitian ini adalah Ketua KUA Jatinangor, para penghulu, dan beberapa pegawai di KUA Jatinangor Kabupaten Sumedang. Mereka diwawancarai secara individual dan bahkan di tempat yang berbeda agar membuat wawancara yang peneliti lakukan mendapatkan hasil yang objektif. Wawancara difokuskan pada efektivitas penerapan Simkah di KUA Jatinangor Kabupaten Sumedang.

\section{HASIL PENELITIAN DAN PEMBAHASAN}

Dari hasil wawancara yang peneliti lakukan dengan Kepala KUA Jatinangor dan pegawai KUA Jatinangor ditemukan bahwa KUA Jatinangor Kabupaten Sumedang sudah menggunakan Sistem Informasi Manajemen Nikah semenjak Simkah itu sendiri diberlakukan, karena diharapkan agar membantu memudahkan dalam mengolah data nikah di KUA Jatinangor dengan sistematis, aman dan akurat. ${ }^{5}$ Perkembangan teknologi informasi yang semakin cepat dan canggih secara tidak langsung memaksa setiap instansi dan lembaga negara untuk mengikuti arus pekembangan tersebut dengan cara memanfaatkan sistem infomasi berbasis digital. Kehadiran Sistem Informasi Manajemen Nikah (SIMKAH) di Kantor Urusan Agama (KUA) dinilai sangat penting untuk diterapkan di tiap-tiap KUA Kecamatan, khususnya di KUA Jatinangor.

Menurut Kepala KUA Jatinangor, saat ini proses pencatatan nikah sudah semakin berkembang dengan difasilitasi oleh sebuah aplikasi yang dinamakan dengan Sistem Informasi Manajemen Nikah, disingkat SIMKAH. Simkah merupakan kebijakan strategis Ditjen Bimas Islam untuk memperbaharui paradigma pelayanan KUA di era digital. Pada awalnya, gagasan pembaharuan administrasi nikah memang sudah ada sejak Ditjen Bimas Islam masih bergabung dengan Ditjen Penyelenggaraan Haji dan Bimbingan Masyarakat Islam. Pada tahun 2006, setelah Bimas Islam berpisah dengan Ditjen Penyelenggaraan Haji dan Umrah, tekad mewujudkan palayanan administrasi berbasis teknologi semakin menguat. Sebelumnya memang telah lahir SIMBIHAJ

${ }^{5}$ Hasil wawancara dengan Asep Kurnia, Kepala KUA Jatinangor Sumedang, pada tanggal 15 November 2019

182 Al-Ahwal Al-Syakhsiyyah : Jurnal Hukum dan Peradilan Islam 
(Sistem Informasi Manajemen Bimas Islam dan Haji), SINR (Sistem Informasi Nikah Rujuk) dan SIKUA, dan akhirnya SIMKAH. ${ }^{6}$

Simkah sendiri memiliki dua tujuan utama yang hendak dicapai adalah: pertama, Sebagai sistem penyeragaman data, dan kedua, sebagai Backup Data yang terintegrasi.

Penyeragaman data tersebut sangat diperlukan dengan harapan data dapat lebih efektif dan efisien. Back-up data diperlukan adalah untuk menyelamatkan dan menghimpun data dari berbagai masalah yang dihadapi seperti bencana alam dan sebagainya. Kehadiran program Simkah yang dikeluarkan oleh pemerintah untuk diterapkan di berbagai KUA di Indonesia diharapkan dapat mengolah data secara cepat dan terkini, sehingga bisa secara tepat, akurat dan efisien ketika dianalisa.

Program SIMKAH memang dirancang agar dapat digunakan dengan mudah oleh semua pegawai KUA di seluruh Indonesia agar terbiasa dengan komputer dan Ilmu Teknologi lain. Dalam perkembangannya, program Simkah banyak mendapatkan respon dari berbagai pihak. Beberapa di antaranya tanggapan positif baik dari operator SIMKAH pada KUA (internal) maupun masyarakat umum (Eksternal). Respon yang membangun ini sangat dibutuhkan oleh pengelola SIMKAH karena pada akhirnya menjadi bahan evaluasi kebijakan pengembangan sistem informasi nikah. Fungsi dan manfaat dari SIMKAH di antaranya:

1. Membangun Sistem Informasi Manajemen Penikahan dicatat di KUA-KUA;

2. Membangun infrastruktur database dengan memanfaatkan teknologi yang dapat mengakomodasi kebutuhan manajemen dan eksekutif;

3. Membangun infrastruktur jaringan yang terintegrasi antara KUA ditingkat daerah sampai Kantor Pusat;

4. Penyajian data yang cepat dan akurat serta mempermudah pelayanan, pengendalian dan pengawasan;

5. Pelayanan bagi publik untuk mendapatkan informasi yang lengkap, cepat dan akurat.

Selain itu, kemampuan program SIMKAH ini secara garis besar adalah:

1. Menambah data, mengedit, menghapus data nikah secara mudah.

2. Mengirim data secara online (internet) secara mudah tetapi juga bisa secara offline yaitu melalui disket, CD atau flash disk.

3. Cara input data yang sederhana namun fleksibel.

4. Program dapat mengecek identitas mempelai melalui berbagai kemungkinan.

5. Program dapat mengecek identitas mempelai melalui berbagai kemungkinan.

${ }^{6}$ https://bimasislam.kemenag.go.id/post/opini/simkah Diakses pada tanggal 20 Desember 2019, Pukul 15.30 WIB. 
6. Tersedianya beberapa laporan standar yang dapat dihasilkan, pada masa mendatang dapat dibuat berbagai laporan sesuai dengan yang diinginkan. Laporan lainnya dapat dibuat sesuai dengan keinginan lewat transfer ke excel.

7. Hanya pemakaian program yang diizinkan yang bisa mengoperasikan.

8. Backup data terkompres, sehingga data yang besar dapat disimpan dalan media penyimpanan yang jauh lebih kecil.

9. Pengiriman data dari KUA ke kantor Kemenag, Kanwil dan Bimas Islam dapat dilakukan dengan sekali kirim (via internet).

10. Update SIMKAH dapat dilakukan secara offline dan online. ${ }^{7}$

Praktik administrasi kependudukan yang berlaku di KUA Jatinangor dalam proses pencatatan nikah telah terfasilitasi cukup baik. Fasilitas ini adalah dengan munculnya aplikasi Sistem informasi Manajemen Nikah atau Simkah. Simkah dalam fungsinya membantu para penghulu dalam tugasnya dan membantu dalam mengamankan data perkawinan di samping data print out di KUA. Simkah terdapat pada aplikasi di komputer, sehingga membuat administrasi pernikahan semakin modern dan teratur dengan baik, karena dikhususkan untuk KUA dan server pusat saja yang dapat membukanya. Data perkawinan yang ada dalam SIMKAH kemudian dikirimkan secara online kepada server pusat di Kemenag Pusat.

Simkah sendiri memiliki beberapa tujuan dan kegunaan, baik itu untuk masyarakat, untuk sistem administrasi, dan untuk KUA yang menggunakan program Simkah itu sendiri. Bagi pihak KUA Jatinangor, penggunaan Simkah merupakan bentuk apresiasi terhadap kebijakan pemerintah yang telah mengeluarkan program berbasis teknologi informasi yang bertujuan untuk meningkatkan kemampuan kerja pegawai KUA Jatinangor, terutama dalam penguasaan Ilmu Teknologi. Dalam rangka meningkatkan kinerja penghulu, serta optimalisasi pencatatan peristiwa nikah, maka sudah sangat tepat jika penguasaan Ilmu Teknologi haruslah dikembangkan. Program Simkah memiliki fungsi dan tujuan yaitu membangun sistem intormasi manajemen penikahan di KUA. membangun infrastruktur database dengan memanfaatkan teknologi yang cepat dan efektif, membangun infrastruktur jaringan yang terintegrasi antar KUA di tingkat daerah hingga Kantor Pusat. ${ }^{8}$ Isi atau fitur dari Simkah itu adalah untuk melengkapi fungsinya, yaitu data master (meliputi tempat KUA, petugas dan juga password ID), rekap (meliputi data berupa jumlah bilangan peristiwa pernikahan pertahun dan melihat rekap peristiwa pernikahan KUA-KUA seluruh Indonesia), grafik (meliputi gambaran grafik pertahun peristiwa pernikahan), detail (meliputi daftar pernikahan mulai dari No. Register, nama calon pengantin, tanggal dan tempat

\footnotetext{
7 Kantor Wilayah Kementrian Agama Provinsi Bengkulu, Buku Panduan Sistem Informasi Manajemen Nikah (SIMKAH), hlm. 2

8 Abdul Djamil, dalam buletin "Penghulu: Layanan Berbasis IT", Menjaga Integritas, Edisi I, (November 2012), hlm. 10.
} 
pernikahan), entry data (meliputi pengisian berkas-berkas peristiwa pernikahan atau akta cerai). ${ }^{9}$

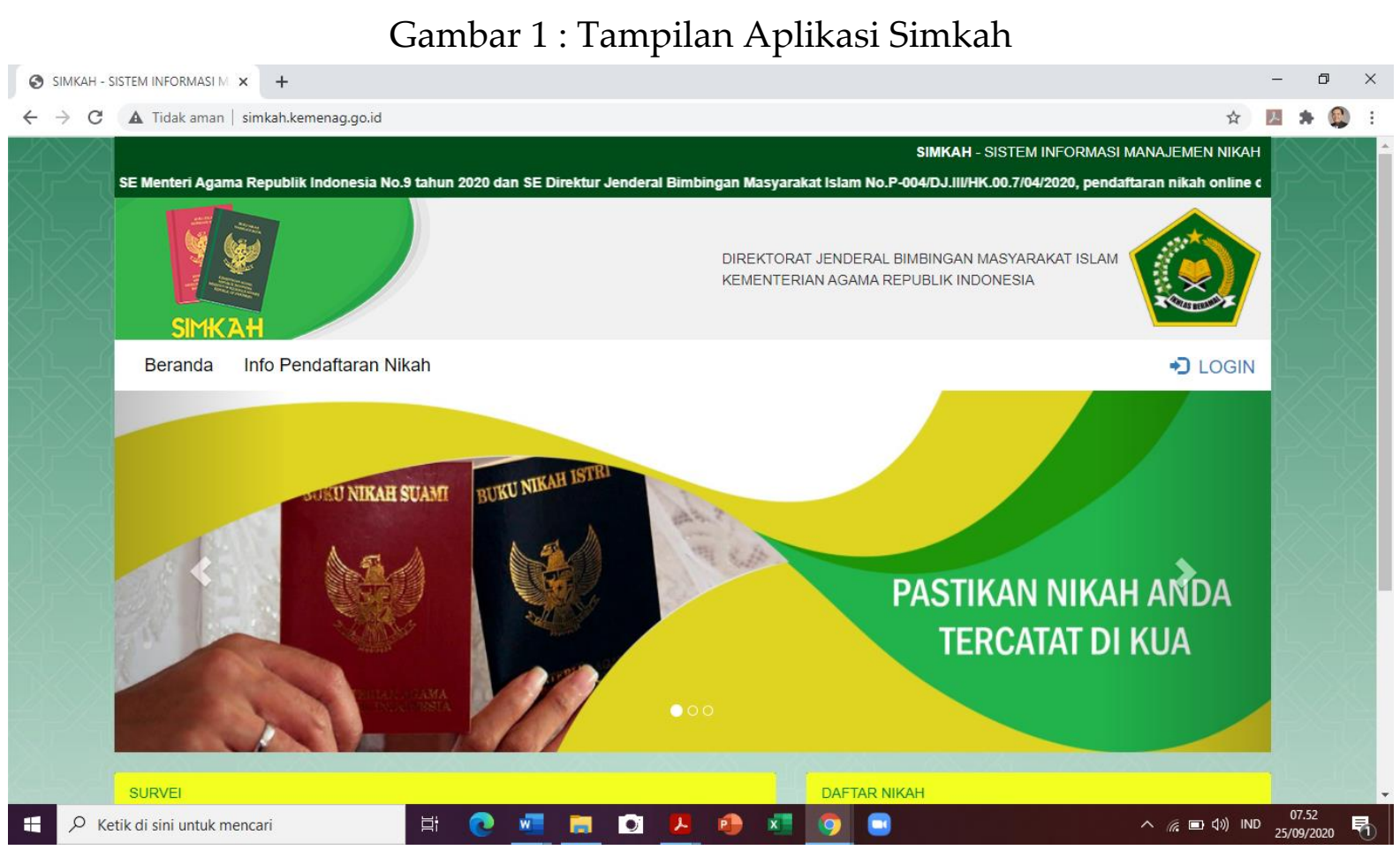

Menurut keterangan kepala KUA Jatinangor, sistem informasi online yang digunakan di KUA Jatinangor tidak hanya dalam bidang pernikahan, talak dan rujuk. Tetapi juga dimanfaatkan dalam hal mendata perwakafan. Kaitannya dengan sistem informasi managemen nikah, KUA Jatinangor juga menyediakan pelayanan yang cepat dan penyimpanan data yang aman, dan memberikan pelayanan secara maksimal. Sehingga sistem informasi manajemen nikah bertujuan untuk melakukan pendataan bagi pasangan yang ingin menikah, dan data pasangan yang sudah menikah, baik secara offline maupun online.

Menurut Kepala Kantor Urusan Agama (KUA) Jatinangor, tujuan utama dari pengelolaan Simkah adalah untuk mendata pasangan nikah, menerima pendapaftaran nikah, serta mengetahui pasangan-pasangan yang akan melakukan pernikahan kedua, poligami, dan data nikah lainnya. Menurutnya efektif atau tidaknya program Simkah dapat diukur melalui keberhasilan pencapaian pengelolaan data di Kantor Urusan

${ }_{9}$ Rizadian Mayangsari, "Efektivitas Penerapan Sistem Informasi Manajemen Nikah (Simkah) di Kantor Urusan Agama Kecamatan Sawahan Kota Surabaya". (Ilmu Administrasi Negara, FISH, UNESA), hlm. 4. Dimuat dalam: http://jurnalmahasiswa.unesa.ac.id/index.php/publ ika/article/download/17005/15453, diakses tanggal 20 Desember 2019, Pukul 14.45 WIB. 
Agama tersebut. Dalam penerapan Simkah untuk tiap-tiap KUA Kecamatan di Indonesia, masih banyak ditemukan bebepara kendala, khususnya di KUA Jatinangor. Baik itu kendala internal maupun kendala eksternal KUA Jatinangor itu sendiri. Kendala-kendala yang terjadi pada dasarnya lebih kepada teknik operasional aplikasi Simkah dan kesiapan pihak KUA Jatinangor dalam menerapkan aplikasi Simkah. Adapun kendala yang terjadi di KUA Jatinangor adalah sebagai berikut : Pertama, Pegawai di KUA Jatinangor yang sedikit membuat proses pendataan pernikahan menjadi terhambat. Kedua, Pegawai KUA Jatinangor tidak terlalu mahir dalam menguasai Ilmu Komputer, karena di KUA Jatinangor kebanyakan diisi oleh pegawai dengan lulusan Sarjana Agama Islam yang tidak begitu mahir dalam Teknologi Informasi. Ketiga, Kurangnya pemahaman mengenai aplikasi Simkah di KUA Jatinangor, dan Keempat. Kurangnya sosialisasi internal terkait Simkah di KUA Jatinangor.

Sehingga pada kenyataannya keberadaan Simkah di KUA Jatinangor yang seharusnya membantu dalam proses pendataan pernikahan yang nantinya akan memudahkan pegawai KUA Jatinangor justru malah membuat pegawai KUA Jatinangor kewalahan dalam proses pendataan melalui Simkah tersebut. Kurangnya pemahaman masyarakat sekitar Jatinangor khususnya yang akan melangsungkan pernikahan juga menjadi salah satu kendala yang tidak dapat dihilangkan.

Gambar 2 : Alur Pelayanan Nikah dalam Simkah 


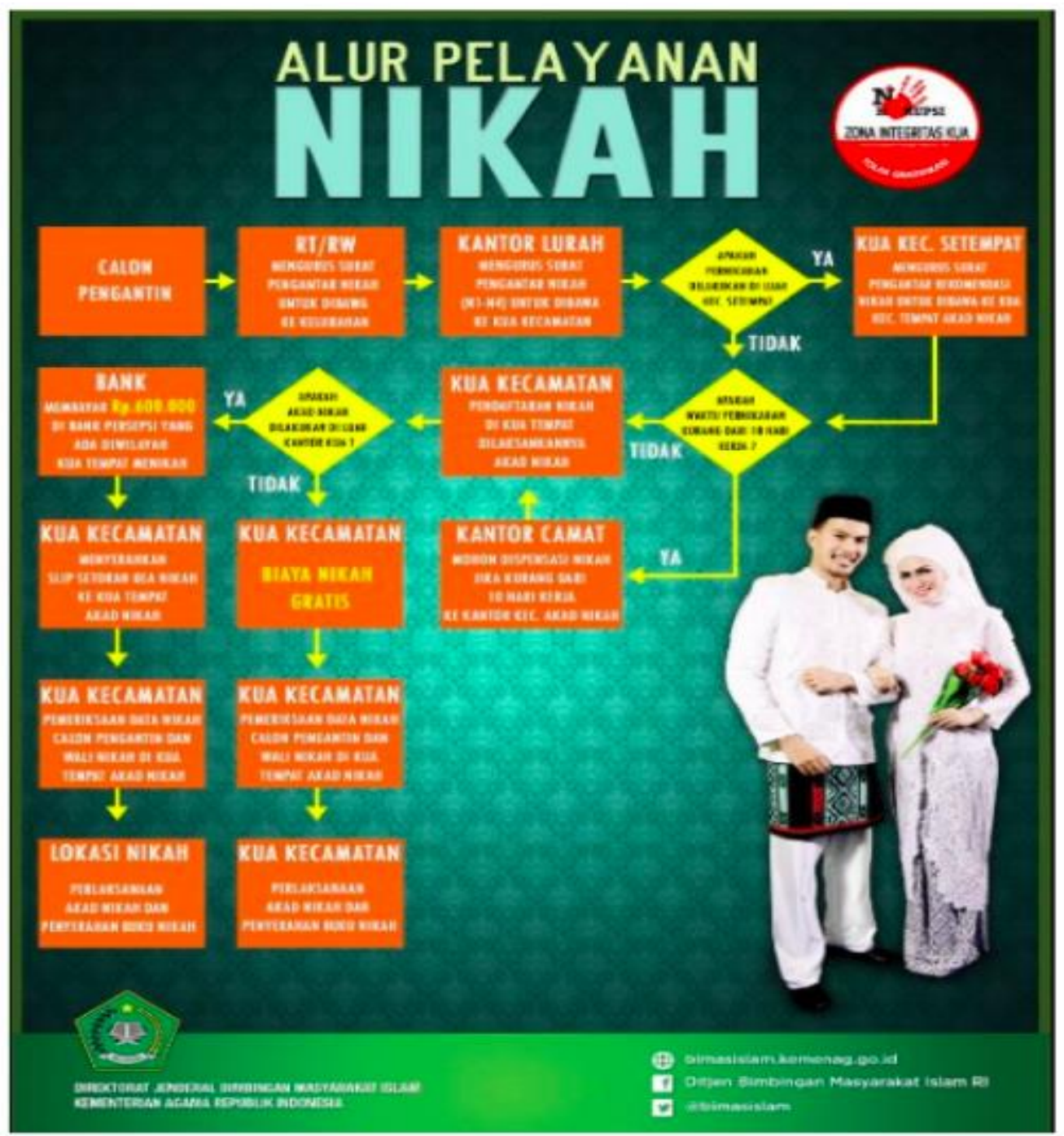

Pada awal diterbitkannya program Simkah itu sendiri, pihak KUA Jatinangor berpendapat bahwa sosialisasi mengenai bagaimana dan seperti apa program Simkah itu sendiri dirasa kurang memberikan pemahaman kepada pegawai KUA Jatinangor. Seharusnya pemerintah melakukan sosialisasi lebih awal terkait program Simkah serta memberikan penanganan apabila terjadi kendala di setiap KUA yang menerapkan program Simkah agar optimalisasi penerapan Simkah menjadi terkendali.

Gambar 3 : Tampilan Log in Simkah 


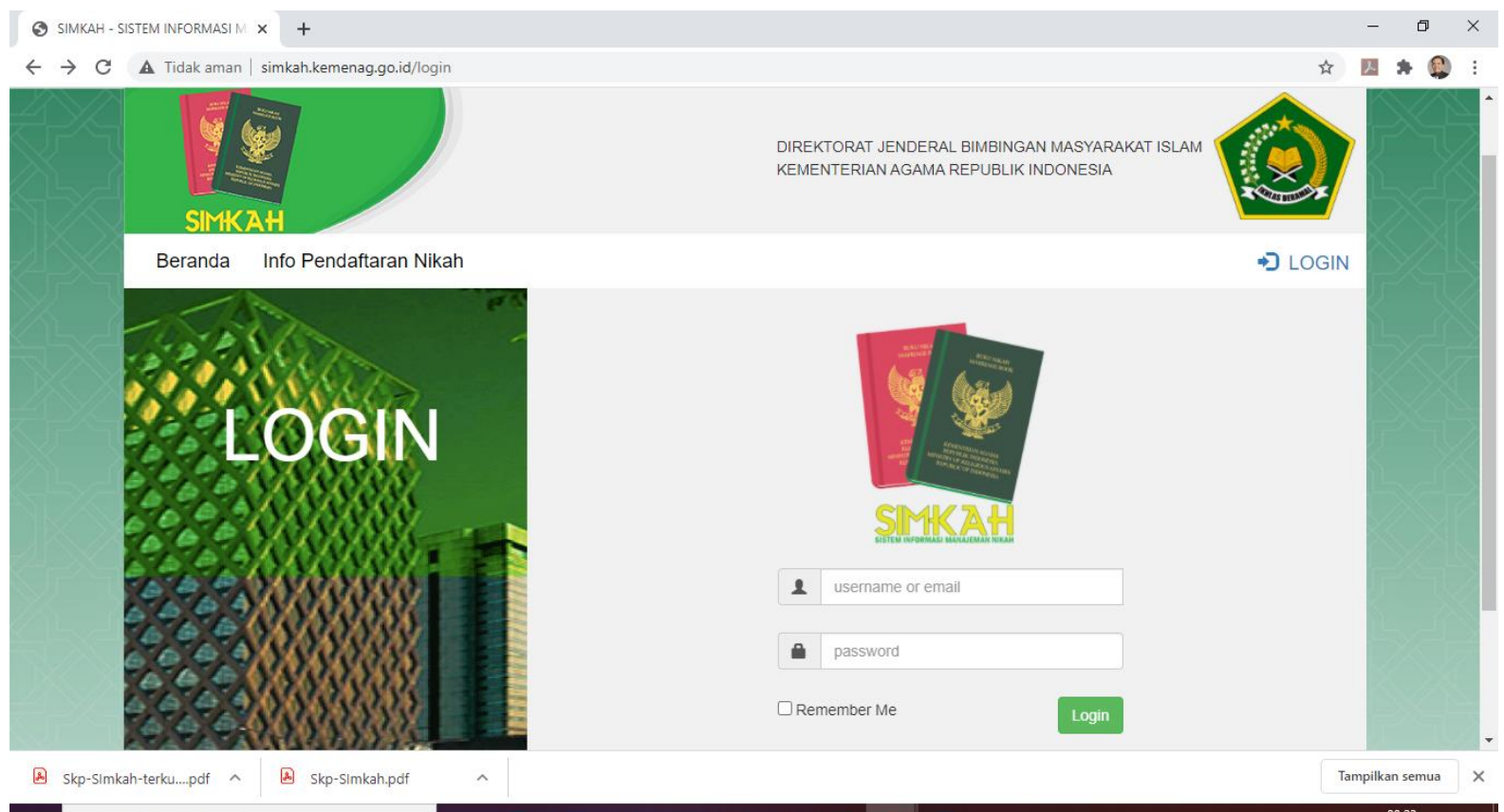

Prosedur Penulisan akta nikah di KUA Jatinangor saat ini telah melalui komputer agar memudahkan pegawai KUA Jatinangor dalam menginput data. Setiap calon pengantin yang hendak mendaftarkan nikah, di samping dengan data di Simkah, diharuskan menyerahkan data secara tertulis berupa N1, N2 dan lainnya. Jadi tidak hanya melalui komputer saja yang ditekankan, namun juga diperlukan bukti tertulis sebagai bentuk arsip suatu pernikahan yang telah berlangsung di wilayah KUA Jatinangor. Arsip yang diserahkan oleh calon pengantin tersebut dapat digunakan dikemudian hari jika ada pasangan pengantin yang menghendaki dibuatkan duplikat akta nikah pernikahannya dikarenakan akta nikahnya rusak atau bahkan hilang.

Proses pendaftaran pernikahan boleh tidak melalui perantara. Perantara yang dimaksud adalah Pembantu Pegawai Pencatat Nikah (P3N) yang sebelum adanya peraturan terbaru mengenai keberadaan $\mathrm{P} 3 \mathrm{~N}$ para masyarakat yang hendak mencatatkan pernikahannya diharuskan melapor kepada P3N. Sehingga calon pengantin boleh mengurus segala persiapannya terkait pemberitahuan kehendak nikahnya kepada KUA tanpa melalui P3N yang keberadaannya saat ini telah dihapus oleh undang-undang. Penulis akan menjelaskan mengenai prosedur penulisan akta nikah yang berlaku di semua KUA khususnya KUA Jatinangor :

1. Calon pengantin mendaftarkan rencana pernikahannya di KUA dengan membawa berkas-berkas dari Desa.

2. Petugas menerima berkas tersebut kemudian memasukkan identitas calon pengantin pada buku agenda pendaftaran dan tak lupa memberikan nomor urut pada berkas calon penganti tersebut.

3. Setelah berkas terdaftarkan, berkas kemudian diberikan kepada operator SIMKAH untuk kemudian dibuatkan slip pembayaran pernikahan apabila calon 
pengantin menghendaki pernikahannya nanti di luar kantor. Operator SIMKAH melanjutkan berkas tadi untuk dimasukkan ke dalam SIMKAH (entri data) hingga dikeluarkan print out lembar pemeriksaan calon pengantin tadi (Model $\mathrm{NB})$.

4. Calon pengantin mendapatkan slip pembayaran kemudian membayarkannya ke bank atau melalui kantor pos dan menyerahkan slip tadi kepada Penghulu atau yang mewakili saat diadakan proses pemeriksaan calon pengantin (pencocokan berkas calon pengantin dengan pengakuan calon pengantin sendiri).

5. Calon pengantin, wali dan saksi-saksi menjalani pemeriksaan seperti di atas hingga pemeriksaan hasil tes kehamilan (tes imunisasi dari Puskesmas). Saat itu pula terkadang diadakan simulasi akad nikah jika calon menghendaki.

6. Pemeriksaan selesai calon pengantin, wali dan saksi diperbolehkan pulang. Berkas calon pengantin diserakan kepada Penghulu untuk diagenda dalam buku pengeluaran buku nikah dan berkas tadi berikan lagi kepada operator SIMKAH satu minggu sebelum akad nikah calon pengantin tadi berlangsung.

7. Mencetak data calon pengantin dalam buku nikah. Dalam hal ini operator SIMKAH sangat berhati-hati karena penulisannya menggunakan sebuah printer yang tidak dapat dihapus jika terjadi kesalahan bahkan jika diperlukan, operator SIMKAH berdiskusi dengan penghulu dalam menentukan data mana yang disepakati oleh calon pengantin saat pemeriksaan untuk digunakan dalam penulisan di buku nikah tadi. Ada 3 macam data dukung untuk penulisan buku nikah :a) KK, b) KTP c) Ijazah, d) Akta Kelahiran

8. Kesemua data dukung di atas merupakan suatu keharusan yang ada dalam berkas calon pengantin saat didaftarkan ke KUA.

9. Setelah buku nikah tercetak, berkas diberikan lagi kepada penghulu yang bertugas melaksanakan pernikahan tadi (melaksanakan tugas pernikahan).

10.Akad nikah berlangsung, buku nikah diserahkan kepada masing-masing mempelai. Warna coklat kemerahan untuk suami sedangkan warna hijau untuk istri. Penghulu kembali ke kantor dengan membawa berkas tadi diberikan kepada operator SIMKAH untuk dicetak Model N (register pernikahan).

11.Kesemua Model $\mathrm{N}$ pernikahan kemudian dibendel menjadi satu dan data pernikahan pengantin yang ada di SIMKAH kemudian dikirim secara online ke server pusat begitu seterusnya.

Sehingga secara otomatis pernikahan pengantin yang terjadi di wilayah KUA Jatinangor tercatat secara nasional, tidak hanya KUA saja yang memiliki catatan mengenai data pernikahannya, namun pusat juga memiliki datanya. Meski demikian, terkadang masih terdapat perbedaan data identitas yang ada di pencatatan nikah. 
Penyebab terjadinya kesalahan tersebut adalah karena human error, dikarenakan kurangnya ketelitian dalam pekerjaannya.

Seperti dalam persoalan ini, tidak hanya pihak pegawai KUA Jatinangor saja yang terkadang kurang teliti, namun dari pihak calon pengantin yang akan melangsungkan pernikahan juga terkadang menyebabkan terjadinya kesalahan. Meski demikian masih ada kesalahan sebagaimana disebutkan dalam data penelitian. Namun meski begitu, pihak KUA Jatinangor khususnya pegawai KUA yang menangani langsung proses pengelolaan data yang berkaitan dengan data pernikahan tetap berusaha secara maksimal dalam menggunakan program Simkah.

SIMKAH merupakan sebuah kebijakan yang dikeluarkan oleh pemerintah yang bertujuan untuk memudahkan masyarakat termasuk para pegawai KUA dalam pengoperasian data-data dan pelayanan pernikahan, talak dan rujuk. Program Simkah dianggap dapat mempermudah dalam pengurusan masalah keagamaan seperti pernikahan, khususnya di bidang hukum keluarga. Regulasi Simkah dapat dikatakan sebagai sebuah aturan tambahan yang bersifat tawsì qi, yaitu aturan yang membuat lebih mudah dalam mengurus pernikahan di KUA. Aturan tambahan yang tidak berasal dari dalil syara kemudian akan masuk dalam bagian regulasi yang bersifat tawsīiqi, seperti halnya terkait aturan mengenai Simkah. Jika dilihat dari manfaatnya, program Simkah tentu menguntungkan dan dapat mempermudah KUA yang menerapkan program Simkah tersebut dalam mendata pernikahan. Program Simkah baru-baru ini telah mengeluarkan sebuah layanan dalam bentuk web yang nantinya tentu akan memudahkan masyarakat dalam mengakses data nikah, termasuk melakukan pendaftaran nikah tanpa harus pergi langsung ke KUA.

Secara umum, regulasi yang dituangkan dalam Keputusan Direktur Jenderal Bimbingan Masyarakat (Dirjen Bimas) Islam No. DJ.II/369 Tahun 2013 Tentang Penerapan SIMKAH pada Kantor Urusan Agama (KUA) Kecamatan, menurut peneliti memiliki keselarasan dengan konsep penerapan hukum melalui mașlahah mursalah. Mașlahah mursalah sendiri merupakan beberapa sifat yang sejalan dengan tindakan serta tujuan syara. Tetapi, tidak ada dalil tertentu dari syara yang membenarkan atau menggugurkannya dan dengan ditetapkan hukum padanya akan tercapai kemaslahatan dan tertolak kerusakan dari manusia. Dalam pengertian lain, maṣlahah mursalah merupakan suatu kemaslahatan yang secara hukum tidak disyariatkan oleh syari', serta tidak ada dalil yang menerangkan atau membatalkannya. ${ }^{10}$

Dalam Islam telah ditegaskan mengenai tujuan ditetapkannya suatu hukum adalah untuk menggapai kemaslahatan bagi manusia. Dalam konteks Simkah, maka sifat kemudahan pelayanan, serta terjaminnya data-data pernikahan yang ada dalam

${ }^{10}$ Abdul Manan, Pembaharuan Hukum Islam di Indonesia, (Jakarta: Kencana Prenada Media Group, 2017), hlm. 177: Lihat juga dalam, Abdul Wahhab Khallaf, Ilmu Ushul Fikih, Edisi Kedua, (terj: Moh. Zuhri dan Ahmad Qarib) (Semarang: Dina Utama Semarang, 2014), hlm. 139.

190 Al-Ahwal Al-Syakhsiyyah : Jurnal Hukum dan Peradilan Islam 
penerapan Simkah menjadi unsur yang paling penting serta memberikan indikasi terkait nilai-nilai kemaslahatan. Pada dasarnya, kebijakan-kebijakan yang dikeluarkan oleh pemerintah adalah untuk meciptakan sebuah kemaslahatan bagi masyarakatnya. Maka penerapan Simkah merupakan bagian penting yang harus dilaksanakan, karena memiliki kegunaan serta berbagai manfaat yang cukup besar dalam penerapan hukum keluarga Islam di Indonesia.

Hal ini tentunya harus menjadi dorongan bagi pegawai KUA Kecamatan, khususnya KUA Jatinangor dalam meningkatkan pemahamannya mengenai Simkah agar penerapan Simkah di KUA Jatinangor menjadi lebih efektif. Efektivitas itu sendiri berhubungan dengan berhasil atau tidaknya sesuatu dalam menggapai tujuan yang telah ditetapkan. Terkait dengan makna efektivitas Simkah di KUA Jatinangor, tentu berkaitan dengan berhasil tidaknya penerapan Simkah di KUA tersebut. Diperlukan teori yang menjadi bahan acuannya, teori disini yaitu teori efektivitas hukum. Teori efektivitas hukum sangat berkaitan dengan daya kerja sebuah hukum dalam mengatur atau memaksa masyarakat untuk taat terhadap hukum itu sendiri.

Maka dapat diartikan bahwa untuk menguji sebuah hukum yang harus memenuhi syarat, yaitu berlaku secara yuridis, berlaku secara sosiologis dan berlaku secara filosofis. ${ }^{11}$ Hukum secara yuridis, sosiologis, dan filosofis, agar dapat diberlakukan tentu memerlukan faktor-faktor yang dapat menunjang keberlakuan hukum agar dapat efektif diterapkan.

Dalam teori efektivitas hukum, terdapat beberapa faktor yang mempengaruhi fungsi hukum berlaku dalam masyarakat. Faktor-faktor tersebut dapat disarikan menjadi empat faktor. ${ }^{12}$ Adanya materi hukum yang baik, Adanya penegak hukum yang baik. Adanya masyarakat hukum yang baik, dan Adanya sarana dan prasarana hukum yang baik.

Masing-masing faktor yang disebutkan dapat dikemukakan secara rinci dalam poin-poin berikut ini:

1. Materi hukum yang baik, yakni adanya ketentuan yang mengatur suatu masalah dalam masayarakat. Di mana ketentuan tersebut tersusun secara baik dan mengandung materi yang baik pula. Materi hukum disebut juga dengan kaidah hukum.

2. Penegak hukum yang baik, bermaksud aparat penegak hukum telah melakukan tanggungjawabnya selaku penegak hukum. Sehingga, hukum akan berlaku secara efektif ketika penegak materi hukum yang ada juga baik.

\footnotetext{
${ }^{11}$ Irwan Jasa Tarigan, Peran Badan Narkotika Nasional dengan Organisasi Sosial Kemasyarakatan dalam Penanganan Pelaku Penyalahgunaan Narkotika, (Yogyakarta: Deepublish, 2017), hlm. 52-53.

${ }^{12}$ Munir Fuady, Teori-Teori Besar "Grand Theory" dalam Hukum, Cet. 3, (Jakarta: Kencana Prenada Media Group, 2014), hlm. 117
} 
3. Masyarakat hukum yang baik, bermaksud bahwa masyarakat secara sadar tunduk dan patuh terhadap ketentuan yang ada.

4. Sarana dan prasaran hukum yang baik, bermaksud bahwa hukum dapat ditegakkan secara efektif jika diimbangi dengan adanya sarana dan prasarana penegakkan hukum. Misalnya, adanya mobilitas penegak hukum dalam menjalankan tugas-tugasnya.

Berdasarkan penjelasan di atas, dapat disimpulkan bahwa sebuah kebijakan hukum dapat diberlakukan kepada masyarakat secara efektif ketika telah memenuhi beberapa faktor pendukungnya, yaitu materi hukum yang tertuang dalam peraturan, adanya pelaksana yang baik, masyarakat serta sarana dan prasarana hukum yang baik. Faktor-faktor tersebut harus ada dan bersifat komulatif, bukan alternatif. Artinya, semua faktor pendukung tersebut harus terpenuhi secara keseluruhan. Dengan demikian, suatu ketentuan akan dapat efektif untuk ditegakkan dalam masyarakat.

Berkaitan dengan efektivitas penerapan Simkah di KUA Jatinangor, menurut Kepala KUA Jatinangor dirasa kurang baik dan tidak terlalu efektif. Karena menurutnya, penerapan Simkah tersebut membuat pegawai KUA Jatinangor dipaksa untuk teliti dan cermat dalam proses administrasi di KUA. Hal tersebut memang bagus bagi para pegawai KUA Jatinangor agar lebih tertib administrasi dan taat prosedur. Namun dikarenakan kurangnya kesiapan menghadapi Simkah serta ketidaktahuan secara menyeluruh terkait program Simkah itu sendiri membuat penerapan Simkah di KUA Jatinangor beralih fungsi dari memudahkan menjadi menyulitkan pegawai KUA Jatinangor karena masih harus menginput data secara manual.

Penerapan Simkah juga membuat masyarakat agar lebih tertib administrasi, jika ada perubahan data atau status pernikahan maka masyarakat harus melakukan update data ke Disdukcapil, berbeda ketika jaman manual, banyak kebijakan yang berlaku di lapangan. Meski begitu, tetap saja penerapan program Simkah di KUA Jatinangor dipandang sangat bagus dalam pelayanan di KUA, terlebih jika program Simkah tersebut disempurnakan dan diintegrasikan dengan aplikasi lain bahkan dari instansi lain seperti Disdukcapil. Maka terkait dengan data kependudukan yang ada nantinya dapat lebih up to date terkait dengan pernikahan, perceraian atau rujuk.

Berdasarkan pemaparan diatas, dapat diketahui bahwa penerapan aplikasi Simkah di KUA Jatinangor dipandang kurang efektif. Meski demikian, menurut Kepala KUA di Jatinangor, kendala-kendala dalam penerapan Simkah tersebut berkaitan dengan para pihak di KUA Jatinangor itu sendiri dan bukan berasal dari kebijakan pemerintah, sehingga membuat program Simkah di KUA Jatinangor menjadi kurang optimal dan tidak terlalu berkembang. Menurutnya, masalah yang paling sering muncul adalah terkait dengan layanan legalisir yang buku nikahnya ternyata palsu, ketika dicek secara online ke KUA penerbit nikah tersebut (KUA tempat menikah) 
ternyata tidak ditemukan. Penerapan Simkah memiliki hambatan tersendiri bagi KUA di seluruh Indonesia dalam hal manajemen aplikasi SIMKAH dari KUA Kecamatan ke pusat. ${ }^{13}$

\section{KESIMPULAN}

Berdasarkan pembahasan di atas, penelitian ini telah sampai pada kesimpulan bahwa penerapan Simkah di Kantor Urusan Agama (KUA) Jatinangor cenderung tidak efektif dilaksanakan. Karena terdapat beberapa hambatan dalam penerapan Simkah itu sendiri. Kemudian kurangnya kesiapan pegawai KUA Jatinangor dalam proses pendataan melalui program Simkah serta minimnya pengetahuan dalam menggunakan Teknologi di KUA Jatinangor membuat program Simkah tidak terlalu memberikan kemudahan dalam proses pendataan.

\section{DAFTAR PUSTAKA}

Abdul Djamil, dalam bulletin. (2012). "Penghulu: Layanan Berbasis IT", Menjaga Integritas, Edisi I.

Abdul Manan. (2017). Pembaharuan Hukum Islam di Indonesia, (Jakarta: Kencana Prenada Media Group., Lihat juga dalam. (2014).

Abdul Wahhab Khallaf, Ilmu Ushul Fikih, Edisi Kedua, (terj: Moh. Zuhri dan Ahmad Qarib) (Semarang: Dina Utama Semarang).

Irwan Jasa Tarigan. (2013). Peran Badan Narkotika Nasional dengan Organisasi Sosial Kemasyarakatan dalam Penanganaan Pelaku Penyalahgunaan Narkotika. Yogyakarta: Deepublish.

Kantor Wilayah Kementrian Agama Provinsi Bengkulu, Buku Panduan Aplikasi Sistem Informasi Manajemen Nikah (SIMKAH).

Kementerian Agama RI. (2013). Buku Panduan Aplikasi Sistem Informasi Manajemen Bimas Islam (SIMBI), (Jakarta: Dirjen Bimas Islam.

Majalah Ditjen Bimas Islam Kemenag RI. (2014). Paradigma Baru KUA,(Jakarta: Edisi No. 1/Tahun 1/2014)

Munir Fuady. (2014). Teori-Teori Besar "Grand Theory" dalam Hukum, Cet. 3, Jakarta: Kencana Prenada Media Group.

Rizadian Mayangsari, "Efektivitas Penerapan Sistem Informasi Manajemen Nikah (Simkah) di Kantor Urusan Agama Kecamatan Sawahan Kota Surabaya". (Ilmu Administrasi Negara, FISH, UNESA), hlm. 4. Dimuat dalam: http://jurnalmahasiswa.unesa.ac.id/index.php/publ

13 Hasil wawancara dengan Bapak Asep Kurnia, Kepala KUA Jatinangor Sumedang, pada tanggal 15 November 2019 
ika/article/download/17005/15453, diakses tanggal 20 Desember 2019, Pukul 14.45 WIB.

Rizadian Mayangsari dan Eva Hany Fanida. (2012). “Penerapan Sistem Informasi Manajemen Nikah (Simkah)". Jurnal Hukum. Vol. 3, No. 1.

Hasil wawancara dengan Bapak Asep Kurnia, Kepala KUA Jatinangor Sumedang, pada tanggal 15 November 2019

https://bimasislam.kemenag.go.id/post/opini/simkah Diakses pada tanggal 20 Desember 2019, Pukul 15.30 WIB. 